\title{
DAFTAR PUSTAKA PENGGUNAAN METODE BERMAIN PERAN DAN MEDIA GAMBAR (ROLE PLAYING) DALAM MENINGKATKAN HASIL BELAJAR IPS TEMA JENIS PEKERJAAN MELALUI DI SD NEGERI LIMO 1 DEPOK
}

\author{
MUNIROH \\ NIM. 825533056 \\ Email : munirohlimosatu@gmail.com
}

Refersnsi

Amiruddin. (2018). Perencanaan Pembelajaran. Yogyakarta: Parama Ilmu.

Arsyad, Azhar \& Asfah, Rahman. (2014). Media Pembelajaran. Jakarta: PT RajaGrafindo Persada.

Arsyad, Arsyad, \& Sulfemi, Wahyu Bagja. (2014). Minat Siswa Tentang Keadministrasian dengan Hasil Belajar Administrasi Perkantoran. Edutecno 9 (2), 40-50.

Arsyad, Arsyad dan Sulfemi, Wahyu Bagja. (2018) Metode Role Playing Berbantu Media Audio Visual Pendidikan dalam Meningkatkan Belajar IPS. Jurnal Pendidikan Ilmu Pengetahuan Sosial Indonesia. 3 (2). 41 - 46.

Badar, Dadan Samsul dan Sulfemi, Wahyu Bagja. (2014). Pengaruh Rasa Percaya Diri dan Motivasi Berprestasi Terhadap Kinerja di Kecamatan Ciampea Kabupaten Bogor. Edutecno. 10 (1), 1-10,

Djamarah, Syaiful Bahr, dan Aswan Zain. 2013. Strategi Belajar Mengajar. Jakarta: PT Rineka Cipta.

Fathurrohman, Muhammad. (2015). Model-model Pembelajaran Inovatif Alternatif Desain Pembelajaran yang Menyenangkan. Yogyakarta: Ar-Russ Media.

Fajartriani, Tia dan Sulfemi, Wahyu Bagja. (2014). Pengaruh Motivasi Kerja Guru dan Iklim Organisasi Terhadap Kinerja Guru SMA Negeri di Kecamatan Cigudeg. Edutecno. $8(1), 17-26$

Hamalik, Oemar. (2010). Kurikulum dan Pembelajaran. Jakarta: Bumi Aksara.

Hamalik, Oemar. (2011). Kurikulum dan Pembelajaran. Jakarta: Bumi Aksara.

Hamalik, Oemar. (2014). Kurikulum dan Pembelajaran. Jakarta: Bumi Aksara.

Sapriya. (2014). Pendidikan IPS. Bandung: PT Remaja Rosdakarya Offset.

Sardjiyo, dkk. (2014). Pendidikan IPS di SD. Tangerang Selatan: Universitas Tebuka. 
Sulfemi, Wahyu Bagja. (2013). Pengaruh Persepsi Siswa atas Kemampuan Pedagogik Guru dan Motivasi Belajar Siswa Terhadap Prestasi Belajar Ilmu Pengetahuan Sosial Siswa (Survei di SMK Swasta Kabupaten Bogor). Edutecno. 7 (2), 17-26.

Sulfemi, Wahyu Bagja. (2014). Pengaruh Motivasi dan Lingkungan Sekolah Terhadap Prestasi Belajar Sejarah Di SMA Negeri Leuwilang Kabupaten Bogor. Fascho : Kajian Pendidikan dan Sosial Kemasyarakatan 9 (2), 42-52

Sulfemi, Wahyu Bagja. (2015). Pengaruh Metode Pembelajaran Kontekstual dan Penggunaan Media Video Pendidikan Terhadap Hasil Belajar IPS. Edutecno 13 (2), 1-10

Sulfemi, Wahyu Bagja. (2016). Hubungan Persepsi Peserta Didik Tentang Kompetensi Guru Mata Pelajaran Sejarah dengan Hasil Belajar Mata Pelajaran Sejarah di Kelas X SMA Negeri 1 Pamijahan Kabupaten Bogor. Fascho, 5 (2), 52-70

Sulfemi, Wahyu Bagja. (2016). Hubungan antara Persepsi Guru pada Kepemimpian Kepala Sekolah dan Motivasi Guru dengan Kinerja guru dalam Proses Pembelajaran di SMA Negeri 1 Ciomas. Fascho : Kajian Pendidikan dan Sosial Kemasyarakatan, $5(1), 36-55$

Sulfemi, Wahyu Bagja. (2016). Perundang-Undangan Pendidikan. Bogor : Program Studi Administrasi Pendidikan STKIP Muhammadiyah Bogor.

Sulfemi, Wahyu Bagja dan Lestari, Ayu Hopilatul. (2017). Korelasi Kompetensi Pedagogik Guru dengan Prestasi Belajar Mata Pelajaran IPS Di SMP Muhammadiyah Pamijahan Kabupaten Bogor. Edutecno. 16 (1), 1-16

Sulfemi, Wahyu Bagja dan Abdul Qodir. (2017). Hubungan Kurikulum 2013 Dengan Motivasi Belajar Peserta Didik Di SMK Pelita Ciampea. Edutecno 17 (2), 1-8.

Sulfemi, Wahyu Bagja. (2017). Analisis Pengaruh Motivasi Dan Disiplin Terhadap Kinerja Guru (Studi Kasus di SMA Negeri 1 Pamijahan Kabupaten Kabupaten Bogor). Prosiding Seminar Nasonal STKIP Muhammadiyah Bogor. 1 (1), 342-357

Sulfemi, Wahyu Bagja dan Supriyadi, Dede. (2018). Pengaruh Kemampuan Pedagogik Guru dengan Hasil Belajar IPS. Edutecno 17 (1), 1-10.

Sulfemi, Wahyu Bagja dan Hilga Minati. (2018). Meningkatkan Hasil Belajar Peserta Didik Kelas 3 SD Menggunakan Model Picture And Picture dan Media Gambar Seri. JPSD. 4 (2), 228- 242.

Sulfemi, Wahyu Bagja dan Setianingsih. (2018), Penggunaan Tames Games Tournament (TGT) Dengan Media Kartu Dalam Meningkatkan Hasil Belajar. Journal of Komodo Science Education (JKSE. 1 (1), 1-14

Sri Anitah W., dkk. (2014). Strategi Pembelajaran Di SD. Tangerang Selatan: Universitas Terbuka.

Yusfiriadi, Yusfitriadi dan Sulfemi, Wahyu Bagja. (2012). Penyelewangan Dana Dalam Dunia Pendidikan. Fascho 1 (1), 1-9 